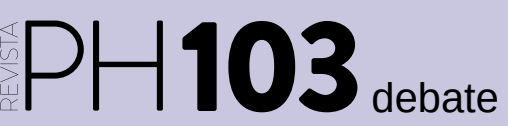

a debate Dilemas del arte urbano como patrimonio

| coordinan Elena García Gayo y Laura Luque Rodrigo

\title{
Construir un patrimonio desde abajo
}

Pablo Navarro Morcillo | Consejería de Educación y Deporte, Junta de Andalucía

URL de la contribución <www.iaph.es/revistaph/index.php/revistaph/article/view/4860>

La problemática que nos atañe al intentar enfocar el conjunto del arte urbano como patrimonio obedece a diferentes prismas y aristas. En primer lugar, nos encontramos con que deberíamos intentar separar las diferentes vertientes que confluyen en un concepto tan grande como ambiguo. Por un lado, manifestaciones dentro del ámbito de la legalidad -una suerte de neomuralismo, en algunos casos- donde la etiqueta de urbano obedece principalmente a un intento de barnizar una práctica que no resulta novedosa. Por otro lado, nos encontramos con ejemplos propios de la ilegalidad, o la alegalidad, como son el grafiti y el street art, que también se ha venido en conocer como posgrafiti. Cada una de estas tipologías responde a unos códigos y mensajes que podríamos entender como parecidos, pero no lo son, ya que su mensaje se dirige a un colectivo concreto, como es el caso de los escritores de grafiti y personas que están familiarizadas con esta práctica; o más amplio, como en el caso del street art, el cual apuesta por una visibilidad en línea con la práctica publicitaria, facilitando su asimilación por un espectro de público más amplio, que conoce e identifica los códigos que se emplean.

Una vez realizadas las acotaciones pertinentes en torno a esta terminología, debemos plantearnos cómo debería ser una posible tutela del patrimonio que vendrían a configurar estas disciplinas. Centrándonos en los elementos propios de la ilegalidad, y la ya mencionada alegalidad, debemos partir de la base de que tanto el grafiti como el street art constituyen manifestaciones efímeras y casi siempre en continua renovación, por lo que su tutela no debería seguir habitualmente los caminos de la restauración o la rehabilitación, sino del registro y la documentación gráfica, así como el mapeado de los diferentes lugares en los que estas manifestaciones resultan más recurrentes ${ }^{1}$.
Al citado carácter temporal de las manifestaciones, debemos añadir una importante falta de conocimiento y documentación de las escenas relativas al grafiti y el street art en España, un hecho que en las dos últimas décadas ha venido siendo remediado por la incipiente publicación de algunas monografías sobre el desarrollo de las escenas en diversos puntos del país, donde podríamos poner el ejemplo de Madrid o Barcelona como los casos más referenciados y mejor estudiados, un paso muy importante de cara a poner en pie un enfoque patrimonial o una puesta en valor, ya que ese conocimiento ayuda a trazar los referentes, influencias y evolución del movimiento en cada latitud, ayudándonos a configurar una especie de "quién es quién" de la disciplina.

Que durante los últimos lustros haya tenido lugar una proliferación de los conocidos festivales de arte urbano obedece de manera general, ya que siempre existen honrosas excepciones ${ }^{2}$, a una política cortoplacista por parte de las instituciones, que buscan una idea idílica, que no existe, de ese grafiti o street art "bueno". En muchos casos estos festivales se reducen a la realización de obras en gran formato en diversos puntos de una localidad por artistas que tienen o han tenido una vinculación con el mundo de la creación transgresora en el espacio público, pero se obvia una necesaria labor de comisariado y de crítica del trabajo realizado que nos lleva a otro elemento a tener en cuenta en estas coordenadas: al igual que ya existe, desde hace décadas, una crítica coherente y rigurosa dentro del arte contemporáneo, ¿existe lo mismo dentro de este amplio paraguas que es el arte urbano? La crítica y el comisariado son aun reducidos y esto puede obedecer, entre otras razones, al estado casi embrionario de la investigación de esta práctica y sus ramificaciones en España y su poca presencia en los ámbitos académicos. 


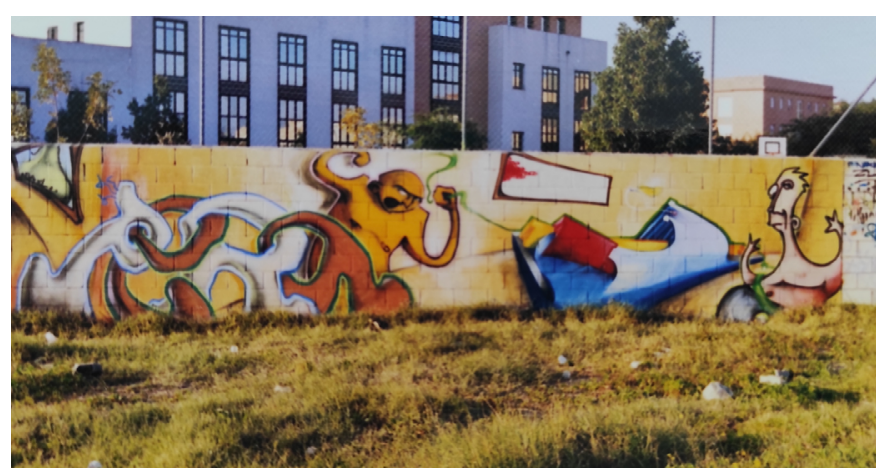

Piezas de Pera y Bimbo en las Escuelas Francesas (Sevilla Este). Finales de la década de 1990 | foto archivo personal de Bimbo

Ante la falta de registros elaborados y de acceso público se antoja necesario, en la construcción de un campo patrimonialista en torno a estas expresiones, llevar a cabo toda una labor de investigación y archivo de la evolución de las escenas de grafiti, sobre todo en la época preinternet, y una recopilación de la memoria oral de los actores y agentes involucrados en dichos ámbitos. Esta tarea no es fácil, ya que los registros que existen suelen ser parte de los archivos privados de los propios escritores $\mathrm{y}$, en los casos de imágenes que fueran publicadas en su momento, forman parte de revistas o fanzines que apenas tuvieron repercusión fuera del movimiento o la cultura hiphop. Quizás es a partir del 2000 cuando comienza a existir un mayor interés por el fenómeno y empieza a traspasar esos lugares comunes en los que habitaba durante la década anterior, dando lugar a una eclosión de publicaciones en páginas web, muchas de las cuales ya no existen, que nos aportan otro ámbito de búsqueda y su consiguiente dificultad: la de los webzines.

Por tanto, y a modo de conclusión, una primera vía de acercamiento por parte de las instituciones y de los investigadores a la normalización de esta tipología de expresiones e intervenciones en el espacio público sería el conocimiento del quién, el cómo y el dónde, a través de la construcción de archivos, tanto de la memoria oral como de elementos e hitos visuales, enfocados a cubrir los orígenes y la desigual evolución de las diversas escenas de grafiti y posgrafiti. Esta labor se antoja esencial

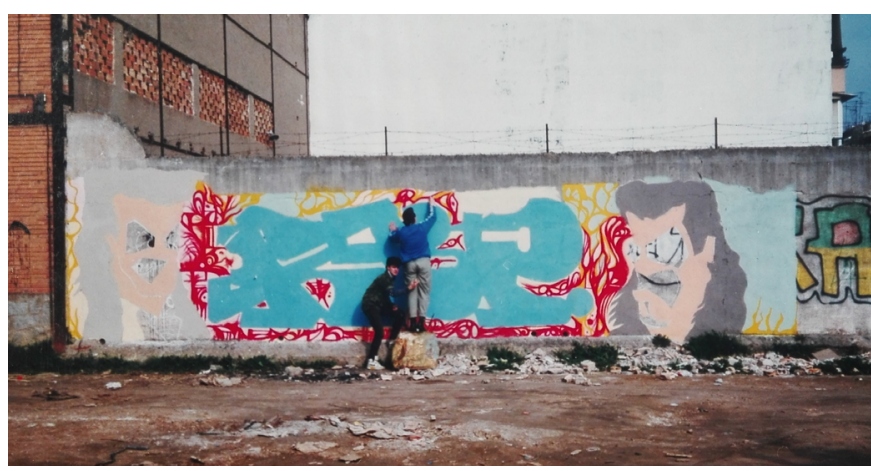

Jam y Shrimp pintando en un solar en la zona de San Pablo, Sevilla, 1991 | foto archivo personal de Jam

para poder calibrar su importancia, impacto e influencia en el ámbito cultural y social de las ciudades y establecer vías de diálogo con el campo del patrimonio cultural.

\section{NOTAS}

1. En el caso de la práctica del grafiti más elaborado, esto nos lleva a conocer la ubicación de los denominados hall of fame mientras que, en el caso del street art o la práctica del bombing dentro de los códigos del grafiti, nos situaríamos en muchas ocasiones en los centros de las ciudades o zonas transitadas.

2. Citaremos como ejemplos el festival Poliniza y el MIAU Fanzara. El primero por su configuración como un festival con mesas redondas y de divulgación científica sobre la materia y, en el caso del segundo, por su concepción como proyecto de museo al aire libre con continuidad en el tiempo, lo que empieza a denotar una labor de comisariado. 